\title{
Endothermy, ectothermy and the global structure of marine vertebrate communities
}

\author{
David K. Cairns ${ }^{1, *}$, Anthony J. Gaston ${ }^{2}$, Falk Huettmann ${ }^{3}$ \\ ${ }^{1}$ Department of Fisheries and Oceans, PO Box 1236, Charlottetown, Prince Edward Island C1A 7M8, Canada \\ ${ }^{2}$ Environment Canada, National Wildlife Research Centre, Ottawa, Ontario K1A 0H3, Canada \\ ${ }^{3}$ Biology and Wildlife Department, Institute of Arctic Biology, EWHALE Lab, University of Alaska, \\ Fairbanks, Alaska 99775-7000, USA
}

\begin{abstract}
Birds and mammals are the leading marine predators at high latitudes, while sharks and other large fish occupy top positions in tropical waters. The present study proposes that temperaturedependent predation success (TPS) explains global patterns of marine vertebrate community structure. Burst speed increases with temperature in ectotherms but is independent of temperature in endotherms. If capture success depends on relative swimming speeds of predator and prey, ectothermic prey will be more vulnerable to attack by endothermic predators at low temperatures. Conversely, high temperatures should enhance the ability of ectothermic predators to prey on endotherms. Pursuit-diving seabirds (penguins, auks and some cormorants) and pinnipeds (seals and sea lions) are ubiquitous in ocean waters with summer surface temperatures cooler than the midteens to low $20 \mathrm{~s}\left({ }^{\circ} \mathrm{C}\right)$ but are virtually absent in warmer regions. We suggest that the near-absence of these animals at low latitudes is due to TPS, as warm water increases the difficulty of capturing fish prey and increases vulnerability to predation by large ectothermic and partially endothermic sharks. Pursuit-diving birds and pinnipeds are virtually absent from warm temperate and tropical waters, even where primary productivity and fisheries data suggest that food supplies are ample. This indicates that the low productivity that prevails in much of the tropical zone cannot explain the worldwide distributional patterns of pursuit-diving birds and pinnipeds. Endothermy in marine communities increases with cooler temperatures and with animal size. Pursuit-diving birds and pinnipeds are sensitive to temperature limits and may suffer important range contractions as oceans warm.
\end{abstract}

KEY WORDS: Predation $\cdot$ Predator-prey interactions $\cdot$ Seabirds $\cdot$ Pinnipeds $\cdot$ Seals $\cdot$ Whales $\cdot$ Marine food webs · Thermal ecology

Resale or republication not permitted without written consent of the publisher

\section{INTRODUCTION}

Upper trophic structure in the world ocean varies greatly with latitude. Seabirds and marine mammals are the chief predators at mid to high latitudes (Lavigne et al. 1989, Brooke 2004), while sharks and other large fish are leading predators in the tropics and subtropics (Cortés 1999). Within taxonomic groups global distribution varies with foraging method and body type. Birds that swim after active prey in the water column (pursuitdivers) are largely restricted to mid and high latitudes (Brooke 2004). Birds that employ other feeding methods, including surface dipping, skimming and pursuit plunging (Ashmole 1971), are widely distributed throughout the world ocean, including the tropics (del Hoyo et al. 1992). Pursuit-diving pinnipeds are abundant only in mid to high latitudes, but whales, including toothed whales that are also pursuit-divers, are found at all latitudes (Perrin et al. 2002, Kaschner et al. 2006).

No general theory has been advanced to explain these patterns. Ainley (1977) and Heath (2002) postulated that the near-absence of pursuit-diving birds and pinnipeds in tropical waters is due to low food abundance there. However, this does not explain why 
toothed whales are common in the tropics and why sharks and other large fish are common in the tropics but rare at high latitudes.

The prospect of accelerated climate change (Solomon et al. 2007) assigns heightened urgency to the need to understand global patterns of marine trophic structure. Latitudinal shifts in isotherms due to ocean warming (McCarthy et al. 2001) may also force communities that are characteristic of particular temperature regimes to shift in latitude (McMahon \& Hays 2006). This has implications for conservation of highlevel marine predators and for commercial fisheries that exploit some of these predators and most of their prey. Examination of climate-change impacts on marine vertebrates has emphasized effects on species at local or regional scales (e.g. climate and tuna recruitment, Lehodey et al. 2003; ice cover and arctic seals, Ferguson et al. 2005; and temperature and seabird breeding success, Kitaysky \& Golubova 2000) rather than community effects at a global scale.

The present study proposes a new hypothesis that uses temperature-based predation dynamics to link predator community structure to ocean temperature regimes. Predictions arising from this hypothesis were tested against distribution patterns of marine vertebrates. An alternate explanation, that food supply controls distribution of predator types, was also examined.

\section{Temperature-dependent predation success: a hypothesis}

Biochemical reaction rates typically increase 2- to 3fold with a $10^{\circ} \mathrm{C}$ rise in temperature (Taylor et al. 1996). In ectotherms internal body temperature is determined by the surrounding environment. Due to the effect of temperature on metabolism, burst speeds in ectotherms typically rise with increasing temperature up to a point of optimal performance (fish, Wardle 1980; lizards, Zhang \& Ji 2004). Consider an ectothermic animal, whose locomotor performance is dependent on ambient temperature, that is attacked by an endothermic bird or mammal whose locomotor performance is independent of temperature. If the outcome of the predation attempt depends on the speed of the prey relative to that of the predator, the probability of prey capture will vary with temperature. This may be called temperature-dependent predation success (TPS).

Forward TPS occurs when an endothermic predator attacks an ectothermic prey. When the predator is ectothermic and the prey is endothermic, rising temperatures improve the locomotor performance of the predator but not the prey. In this case increased temperature will enhance the success rate of the predator. This is termed reverse TPS.
Christian \& Tracy (1981) documented forward TPS in Galapagos hawk Buteo galapagoensis predation on hatchling land iguanas Conolophus pallidus. Hawk predation success was $67 \%$ when iguana sprint speed was impaired by cool conditions but fell to $19 \%$ when iguana locomotor performance improved in warm conditions. Reverse TPS was demonstrated in laboratory experiments by Greenwald (1974), who found that strike velocity and capture success of gopher snakes Pituophis catenifer attacking mice Mus musculus increased with temperature. TPS has not been experimentally tested in aquatic systems, although winter nocturnality in stream salmonids has been interpreted as a mechanism to reduce predation risk from endothermic predators at a time when low temperatures impair fish locomotion (Valdimarsson \& Metcalfe 1998).

TPS effects may occur within an ectothermic species (examples above) or across species. Fish exhibit a variety of biochemical pathways that mitigate the depressing effect of low temperature on metabolic performance, and species adopt those pathways that optimize swimming performance for the temperature regimes they occupy (Taylor et al. 1996). These adaptations are most effective at low temperatures, so that fish of different species, tested in the temperature to which they are best adapted, display burst speeds that are independent of temperature up to ca. $15^{\circ} \mathrm{C}$ (Wilson et al. 2001). Above $15^{\circ} \mathrm{C}$, burst speeds of thermally adapted species increase with temperature (Wilson et al. 2001). This means that, when considering a set of fish species that are adapted to a range of thermal environments, a relation between temperature and endothermic predator success should be strongly evident only in waters warmer than $15^{\circ} \mathrm{C}$.

Marine birds and mammals prey on fish and invertebrates where forward TPS may occur. Marine birds and mammals are also preyed on by sharks, including both ectothermic and partially endothermic species (Cortés 1999, Bernal et al. 2001). High temperatures should favour successful attacks by ectotherms on birds and mammals (reverse TPS); hence, TPS may affect birds and mammals as both predators and prey.

The present study proposes that TPS is a major structuring force in global marine communities, favouring birds and mammals as top predators in cold regions but inhibiting their role in warm waters. Specific predictions follow:

(1) Because burst swimming speeds of thermally adapted fish species vary with temperature above $15^{\circ} \mathrm{C}$ but not below it, we expect that the role of birds and mammals in marine communities will diminish with rising sea temperatures across areas where mean temperatures are $\geq 15^{\circ} \mathrm{C}$. Below $15^{\circ} \mathrm{C}$ there will be no systematic change with temperature in the importance of birds and mammals. 
(2) Since TPS is based on the relative swimming performance of predator and prey, temperature dependence should be greatest when a predator attacks by rapidly swimming toward its prey in open water and the prey attempts to escape by swimming. Hence, prediction (1) should apply particularly to birds and mammals that forage by pursuit-diving.

(3) Other feeding methods used by marine birds and mammals include approaching at high speed by aerial plunging, seizing prey that has limited mobility, surprising prey in benthic hiding places and filter-feeding (Ashmole 1971, Heithaus \& Dill 2002). The success of these methods does not hinge on the relative prowess of rapid-powered swimming by predator and prey. Hence, we expect no systematic change with temperature in the importance of non-pursuit-diving birds and mammals in marine communities.

(4) Toothed whales swim more rapidly than pursuitdiving birds and pinnipeds (Croxall \& Lishman 1987, Johnsgard 1987, Williams 2002). Hence, the tempera- ture at which TPS constrains predation success should be higher in toothed whales than in pursuit-diving birds and pinnipeds. We therefore expect that toothed whale distributions will include waters warmer than those used by pursuit-diving birds and pinnipeds.

We tested these predictions by examining patterns of distribution and abundance of marine vertebrates in relation to sea surface temperature (SST).

\section{METHODS}

Sources of data on distribution and abundance of marine vertebrates and on commercial fish landings are listed in Table 1.

The present study considered pursuit-diving birds to include penguins (Spheniscidae), diving petrels (Pelecanoididae), auks (Alcidae) (except the planktivorous Aethia, Ptychoramphus and Alle) and those cormorants (Phalacrocoracidae) that have an exclusively marine

Table 1. Sources of data on distribution, abundance, and landings of marine vertebrates

\begin{tabular}{|c|c|c|c|c|}
\hline Region & $\begin{array}{l}\text { Fish and fishery } \\
\text { landings }\end{array}$ & Birds & Pinnipeds & Whales \\
\hline $\begin{array}{l}\text { Northeast } \\
\text { Pacific }\end{array}$ & $\begin{array}{l}\text { DFO }(1987,1990) \\
\text { NOAA }(1990) \\
\text { FAO }(2003)\end{array}$ & $\begin{array}{l}\text { Lensink (1984), } \\
\text { Everett \& Anderson (1991), } \\
\text { Rodway (1991), } \\
\text { Manuwal \& Thoresen (1993), } \\
\text { Carter et al. (1995), } \\
\text { Drost \& Lewis (1995), } \\
\text { Wallace \& Wallace (1998) }\end{array}$ & \multicolumn{2}{|l|}{$\begin{array}{l}\text { Stewart (1997), } \\
\text { Ferrero et al. (2000), } \\
\text { Forney et al. (2000), } \\
\text { Baird (2001) }\end{array}$} \\
\hline Southeast Pacific & & Duffy et al. (1984) & & \\
\hline $\begin{array}{l}\text { Northwest } \\
\text { Atlantic }\end{array}$ & $\begin{array}{l}\text { NOAA (1990), } \\
\text { NAFO (1993) }\end{array}$ & $\begin{array}{l}\text { Buckley \& Buckley (1984), } \\
\text { Evans (1984a), } \\
\text { Lock et al. (1994) }\end{array}$ & \multicolumn{2}{|c|}{$\begin{array}{l}\text { Hammill \& Stenson }(1997,2000), \\
\text { Kingsley (1998), } \\
\text { Waring et al. (2000), } \\
\text { Adam \& Garcia (2003) }\end{array}$} \\
\hline $\begin{array}{l}\text { Southwest } \\
\text { Atlantic }\end{array}$ & & $\begin{array}{l}\text { Croxall et al. (1984), } \\
\text { Antas (1991), } \\
\text { Escalante (1991), } \\
\text { Gandini et al. (1996), } \\
\text { Bingham (1998), } \\
\text { Yorio et al. (1999) }\end{array}$ & \multicolumn{2}{|l|}{ Reijnders et al. (1993) } \\
\hline Northeast Atlantic & & Evans (1984b) & \multicolumn{2}{|l|}{ Harris et al. (1995) } \\
\hline North Atlantic & $\begin{array}{l}\text { Welch et al. (1992), } \\
\text { FAO (1994, 2006), } \\
\text { Bundy et al. (2000), } \\
\text { Guénette et al. (2001), } \\
\text { Baum et al. (2003), } \\
\text { Fonteneau (2004) }\end{array}$ & $\begin{array}{l}\text { Welch et al. (1992), } \\
\text { Bundy et al. (2000), } \\
\text { Guénette et al. (2001) }\end{array}$ & $\begin{array}{l}\text { Welch et al. (1992), } \\
\text { Bundy et al. (2000), } \\
\text { Guénette et al. (2001) }\end{array}$ & $\begin{array}{l}\text { Welch et al. (1992), } \\
\text { Bundy et al. (2000), } \\
\text { Finley (2001), } \\
\text { Guénette et al. (2001), } \\
\text { Perrin et al. (2002) }\end{array}$ \\
\hline Southeast Atlantic & & Cooper et al. (1984) & \multicolumn{2}{|l|}{ Shaughnessy (1985) } \\
\hline Southwest Indian & & Cooper et al. (1984) & & \\
\hline Northwest Pacific & & Hasegawa (1984) & & \\
\hline Southwest Pacific & & Robertson \& Bell (1984) & Donoghue (1997) & \\
\hline World & & $\begin{array}{l}\text { del Hoyo et al. (1992), } \\
\text { Johnsgard (1993), } \\
\text { Williams (1995), } \\
\text { Gaston \& Jones (1998), } \\
\text { Karpouzi (2005) }\end{array}$ & $\begin{array}{l}\text { Riedman (1990), } \\
\text { Kaschner et al. (2006) }\end{array}$ & $\begin{array}{l}\text { Perrin et al. (2002), } \\
\text { Kaschner et al. (2006) }\end{array}$ \\
\hline
\end{tabular}


distribution and a pelagic or mixed pelagic/benthic foraging habit (Cairns 1986). Shearwaters Puffinus spp. were not included because their foraging repertoire includes plunging as well as pursuit-diving (Ashmole 1971). We classed true seals (Phocidae) and eared seals (fur seals and sea lions, Otariidae) as pursuitdiving pinnipeds, although these animals also use other foraging methods including benthic searching (Bowen et al. 2002, Heithaus \& Dill 2002). Where data were sufficient, we determined boundaries beyond which populations of pursuit-diving birds and pinnipeds fell to nil or minimal levels. We use the term 'substantial range' to refer to the area inside these boundaries.

For ocean coastlines that follow an approximate north-south axis and where data were sufficient, we compiled summer populations of pursuit-diving birds and pinnipeds by region (data sources in Table 1). We excluded northern elephant seals Mirounga angustirostris from this analysis because of their deepocean foraging habitat (Le Boeuf et al. 2000). We multiplied the number of breeding birds by 1.35 to include pre-breeders (Cairns et al. 1991). Summer densities of pursuit-diving birds and pinnipeds were calculated by dividing regional populations by the area of continental shelf/slope, measured to the $2000 \mathrm{~m}$ isobath. Mean reported commercial fisheries landings were calculated for the 1980s, prior to the collapse of major groundfish stocks (sources in Table 1).

SSTs were provided by the US Navy (1981). Marine primary productivity zones were from www.marine. rutgers.edu/opp, derived by the method of Behrenfeld \& Falkowski (1997).

\section{RESULTS}

Pursuit-diving birds and pinnipeds have similar world ranges, and both occupy all northern and southern regions of the world ocean except the central Arctic basin and the interior of Antarctic ice shelves (Fig. 1). World range edges approximately correspond to summer SST isotherms between the mid-teens and the low 20s $\left({ }^{\circ} \mathrm{C}\right)$. Pursuit-diving birds and pinnipeds occupy only small and scattered areas within a broad circumequatorial belt. Monk seals Monachus spp. occupy (or occupied) areas of the Hawaiian chain, the Caribbean, the Mediterranean and the adjacent Atlantic. Galapagos penguins Spheniscus mendiculus, sea lions Zalophus wollebaeki and fur seals Arctocephalus galapagoensis inhabit upwelled waters around the Galapagos Islands, which form a temperate enclave (SST 15 to $22^{\circ} \mathrm{C}_{i}$ Boersma 1978, Dellinger \& Trillmich 1999) within the tropical zone. Of the 8.3 million $\mathrm{km}^{2}$ of tropical waters (excluding the Galapagos enclave) whose primary productivity is medium or high (>150 $\left.\mathrm{g} \mathrm{C} \mathrm{m}^{-2} \mathrm{yr}^{-2}\right)$, none are occupied by pursuitdiving birds and $418000 \mathrm{~km}^{2}(5.1 \%)$ are occupied by pinnipeds (Figs. 1 \& 2).

Edges of substantial range (and mean summer SST) along ocean coastlines are the California-Mexico border (birds, $18^{\circ} \mathrm{C}$ ) and Baja California (pinnipeds, $27^{\circ} \mathrm{C}$ ) in the northeast Pacific; northern Peru (birds, $20^{\circ} \mathrm{C}$ ) in the southeast Pacific; Cabot Strait (birds, $13^{\circ} \mathrm{C}$ ) and the southern Scotian Shelf (pinnipeds, $16^{\circ} \mathrm{C}$ ) in the northwest Atlantic; the Valdez Peninsula, Argentina (birds, $16^{\circ} \mathrm{C}$ ), and the Uruguay-Brazil border (pinnipeds,

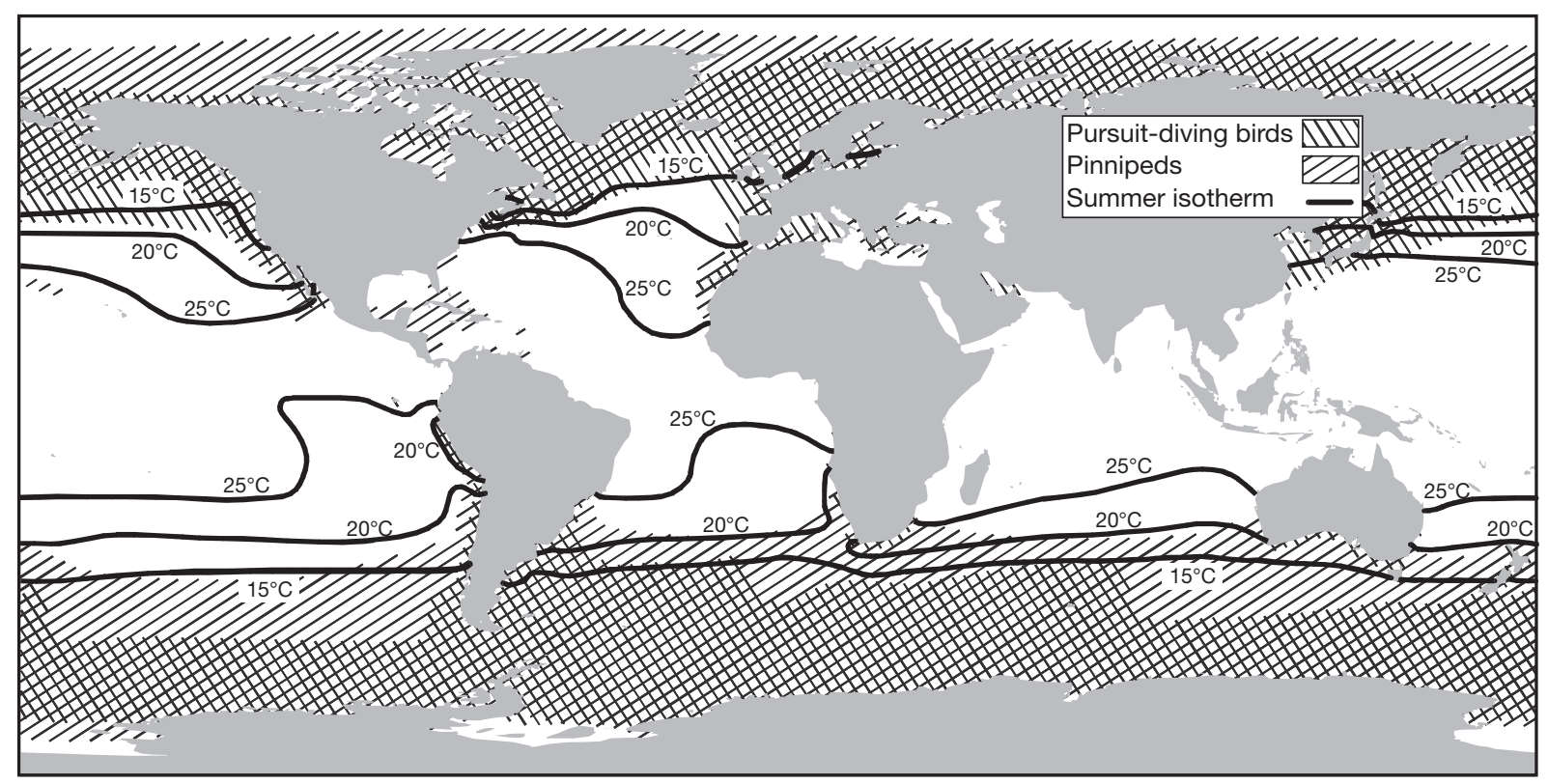

Fig. 1. World distributions of pursuit-diving birds and pinnipeds, including the former range of the extinct Caribbean monk seal, and summer (July and January) sea surface temperature (SST) isotherms 


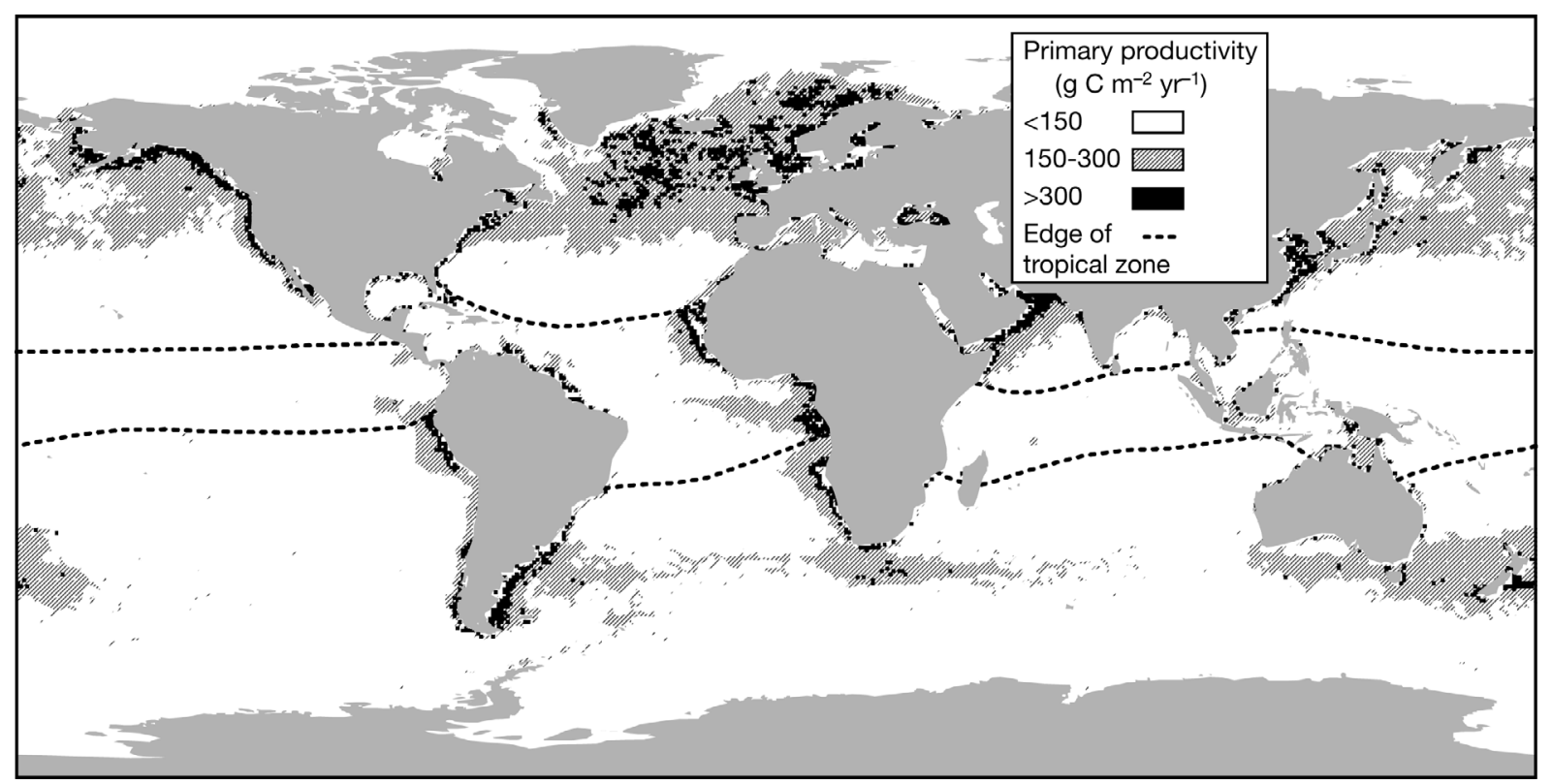

Fig. 2. Marine primary productivity, from www.marine.rutgers.edu/opp as derived by the method of Behrenfeld and \& Falkowski (1997), and tropical zone boundaries, from Garrison (1993)

$21^{\circ} \mathrm{C}$ ) in the southwest Atlantic; the Scottish-English border (birds and pinnipeds, $13^{\circ} \mathrm{C}$ ) in the northeast Atlantic; north-central Namibia (birds and pinnipeds, $18^{\circ} \mathrm{C}$ ) in the southeast Atlantic; Algoa Bay, South Africa (birds, $22^{\circ} \mathrm{C}$ ) in the southwest Indian Ocean; Hokkaido Island, Japan (birds, $15^{\circ} \mathrm{C}$ ) in the northwest Pacific; and southern (birds, $13^{\circ} \mathrm{C}$ ) and northern (pinnipeds, $16^{\circ} \mathrm{C}$ ) South Island, New Zealand, in the southwest Pacific.

For birds mean summer SSTs $( \pm \mathrm{SD})$ at substantial range edges are $16.4 \pm 3.3^{\circ} \mathrm{C}$ (range 13 to $22, \mathrm{n}=9$ ). Mean summer SSTs at substantial range edges are $14.5 \pm 2.1^{\circ} \mathrm{C}$ (range 13 to $16, \mathrm{n}=2$ ) for phocids and $20.5 \pm 4.8^{\circ} \mathrm{C}$ (range 16 to $27, \mathrm{n}=4$ ) for otariids. Mean summer SSTs at substantial range edges do not differ significantly among groups (ANOVA on log-transformed data, $F=2.3, \mathrm{p}=0.14$ ).

Summer densities (animals $\mathrm{km}^{-2}$ of continental shelf/ slope) of pursuit-divers were estimated for birds and pinnipeds in the northeast Pacific and northwest Atlantic and for birds in the southwest Atlantic. In all cases densities varied irregularly through latitudinal zones up to the edge of substantial range, where densities fell to 0 or near 0 (Fig. 3).

Reported commercial fisheries landings $\mathrm{km}^{-2}$ of shelf/ slope were calculated for the northeast Pacific and the northwest Atlantic. Landings $\mathrm{km}^{-2}$ showed highest values at middle latitudes (Fig. 4). No sharp decline in landings $\mathrm{km}^{-2}$ of shelf/slope was evident at the range boundaries of pursuit-diving birds and pinnipeds. In the northeast Pacific the ranges of pursuit-diving birds and pinnipeds included the region (California) with the highest reported landings $\mathrm{km}^{-2}$. In the northwest Atlantic the area of highest reported landings $\mathrm{km}^{-2}$ (New York to Virginia) was outside the ranges of pursuit-diving birds and pinnipeds.

Composition of principal vertebrate groups in North Atlantic food webs varies by temperature zone and body size (data sources in Table 1) (Fig. 5). Small ( $<25 \mathrm{~cm}$ body length) and medium-sized $(0.25$ to $1 \mathrm{~m})$ fish are prominent in food webs in tropical, warm temperate and cold temperate zones. Small fish and planktivorous alcids (the dovekie Alle alle) are important in Arctic marine food webs. Pursuit-diving birds and pinnipeds are major components of Arctic and cool temperate food webs. Tunas are important in tropical and warm temperate waters up to summer isotherms in the mid-teens $\left({ }^{\circ} \mathrm{C}\right)$. Sharks are present in all North Atlantic temperature zones, but their area of prominence extends from the tropics only to summer isotherms in the mid to low teens $\left({ }^{\circ} \mathrm{C}\right)$. Toothed whales are prominent in food webs in all temperature zones. Baleen whales occupy all temperature zones, although tropical waters are generally used as wintering quarters where little feeding occurs (Corkeron \& Connor 1999).

\section{DISCUSSION}

Pursuit-diving birds and pinnipeds have remarkably similar world distributions. Both groups are present throughout cool and cold regions of the world ocean, 

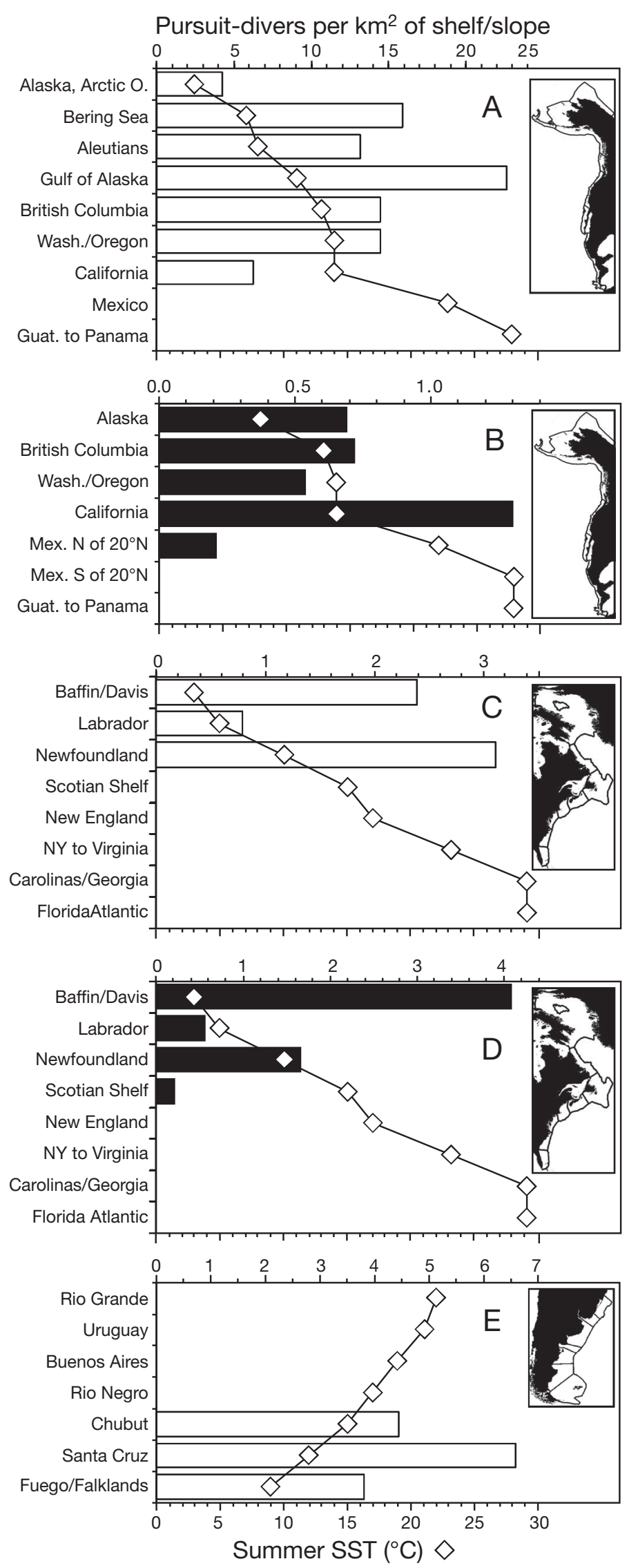

and range edges generally occur in waters whose mean summer SST is between the mid-teens $\left({ }^{\circ} \mathrm{C}\right)$ and the low 20s $\left({ }^{\circ} \mathrm{C}\right)$. Swimming speeds in thermally adapted fish species increase with temperature in water warmer than $15^{\circ} \mathrm{C}$ (Wilson et al. 2001). We interpret the ubiquity of pursuit-diving birds and pinnipeds in waters where summer SST is below the mid-teens $\left({ }^{\circ} \mathrm{C}\right)$, and their near-absence in waters with summer SST warmer than the low $20 \mathrm{~s}\left({ }^{\circ} \mathrm{C}\right)$, as due to difficulty in capturing fish whose swimming performance is enhanced by temperatures above the $15^{\circ} \mathrm{C}$ threshold. Otariid pinnipeds are faster swimmers than phocids (Fish 2002), which may explain why otariid distributions extend into waters warmer than those of phocids.

We evaluated distributions against SST, which reflects temperature in the well-mixed surface layer. All dives by air-breathing animals occur at least partly in this layer, but some also reach colder waters below. Schreer et al. (2001) measured dive depths of 11 species of pursuit-diving birds and pinnipeds. Two Antarctic pinnipeds (Weddell seal Leptonychotes weddellii and southern elephant seal Mirounga leonina) were deep divers $(\geq \sim 200 \mathrm{~m})$; for other species the mean of maximum depth attained was $38 \mathrm{~m}$ (range 10 to $89 \mathrm{~m}$ ). Thickness of the surface layer varies seasonally from a minimum in summer (typically $\sim 25 \mathrm{~m}$ ) to a maximum in late winter (typically $\sim 75$ to $100 \mathrm{~m}$ ) (Alexander \& Penland 1996); hence, pursuit-diving birds and pinnipeds may experience water temperatures colder than SST more frequently in summer than in winter.

In contrast to pursuit-diving birds and pinnipeds, toothed whales and non-pursuit-diving birds occupy all ocean temperature zones (Ainley \& Boekelheide 1983, del Hoyo et al. 1992, Perrin et al. 2002). Toothed whales are able to occupy warm water because their superior swimming ability, relative to pursuit-diving birds and pinnipeds, enables them to capture fish even where warm water increases fish swimming speeds. Non-pursuit-diving birds can occupy warm water because swimming performance does not control their ability to capture food.

Warm water improves the locomotor performance of ectothermic sharks and facilitates the maintenance of elevated body temperatures in partially endothermic sharks, which lack effective thermal insulation. Hence, the ability of these predators to capture birds and mammals should increase with water temperature

Fig. 3. Densities of pursuit-diving birds (white bars) and pinnipeds (black bars) on the continental shelf and slope in relation to mean summer sea surface temperature (SST) (diamonds) along continental margins of the $(A, B)$ northeast Pacific, $(C, D)$ the northwest Atlantic and $(E)$ the southwest Atlantic. Inset maps show blocks of continental shelf/slope for which pursuit-diver densities are plotted 

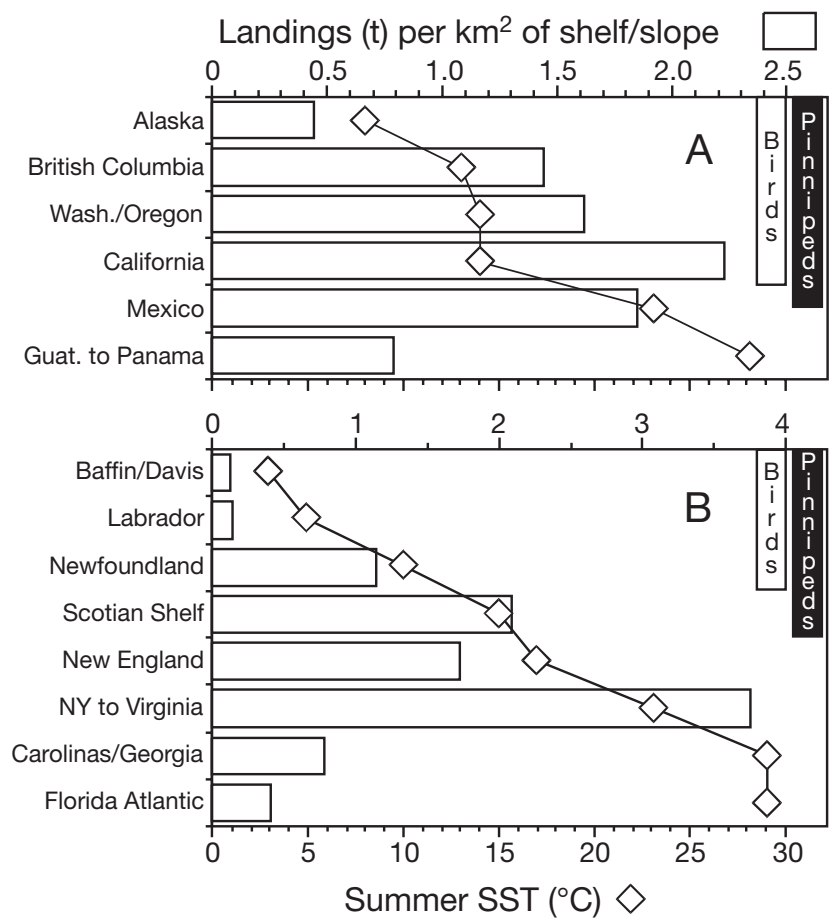

Fig. 4. Mean reported fisheries landings in the $1980 \mathrm{~s} \mathrm{~km}^{-2}$ continental shelf and slope in the (A) northeast Pacific and (B) northwest Atlantic. Vertical bars show the extent of substantial distributions of pursuit-diving birds and pinnipeds in summer

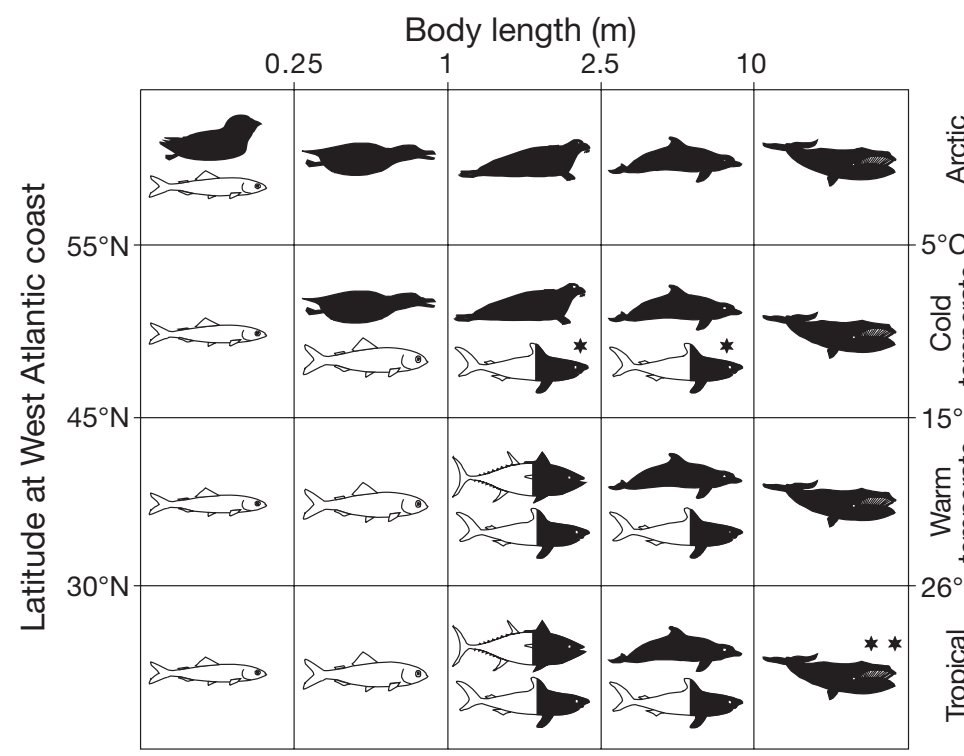

Fig. 5. Principal vertebrate components of food webs in the North Atlantic by temperature zone, body length and thermal status. Vertebrate groups include small fish, medium-sized fish, sharks, tunas, planktivorous birds, pursuit-diving birds, pinnipeds, toothed whales and baleen whales. White symbols represent ectotherms, black symbols represent endotherms, and black and white symbols represent groups that include partial endotherms. A single asterix means that the group chiefly occupies the southern part of the zone. A double asterix means that the group uses the zone chiefly as non-feeding wintering grounds. See Table 1 for data sources

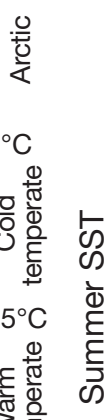

(reverse TPS). Shark predation on pinnipeds has been widely reported (Riedman 1990, Weller 2002) especially near the warm edges of the northern and southern pinniped range (e.g. California, Klimley et al. 2002; Guadalupe Island, Gallo-Reynoso \& FigueroaCarranza 1992; and Nova Scotia, Bowen et al. 2003). One South African study (Martin et al. 2005) documented 2088 great white shark Carcharodon carcharias attacks on cape fur seals Arctocephalus pusillus. At Sable Island, Canada, 25 to $45 \%$ of harbour seal Phoca vitulina pups born in the mid-1990s were later ound beached as shark-killed carcasses (Lucas \& tobo 2000), and shark kills of juveniles and adults re a major contributor to a population crash (Bowen 2003). Pinnipeds inhabiting the tropics suffer extensive shark predation, and many animals exhibit (Hiruki et al. 1993, Weller sharks to swim (Westlake \& Gilmartin 1990). The abundance of reports of shark predation on pinnipeds uggests that such predation may be sufficiently ense to affect pinniped populations near their northern and southern range edges and to prevent advancement into warmer waters.

Randall et al. (1988) described shark-induced injuries to jackass penguins Spheniscus demersus in South Africa. Elsewhere, there are relatively few reports of shark attacks on pursuitdiving birds. Non-pursuit-diving birds that inhabit the tropics generally spend a high proportion of their time in flight, which lowers the risk of shark predation (Ainley \& Boekelheide 1983). A highly airborne lifestyle is not a viable option for pursuit-diving birds because these birds are either flightless (penguins) or have an energetically costly flapping flight (others).

Salmon pursued by pinnipeds and fur seals pursued by sharks lead their attackers on erratic zigzag paths (Bigg et al. 1990, Martin et al. 2005). The success of predatory attacks thus depends on speed along sharply curved paths as well as straight-line speed (Howland 1974, Domenici 2001). Straightline swimming speed of ectothermic fish increases with temperature (Webb 1978, Domenici \& Blake 1997), and it seems likely that rising temperature also increases speed along curved routes. Sensory systems are also important in predator-prey interactions. 
Fritsches et al. (2005) reported that a specialized eyewarming system in swordfish Xiphias gladius generates a 10-fold improvement in capacity to resolve rapidly moving objects. If the relation between water temperature and temporal visual resolution is general in fish, warm water should improve the ability of ectothermic fish to identify and visually track predators and to take rapid and appropriate evasive action.

The marine vertebrate community structure of the North Atlantic shows an increase in endothermy with animal size and water coldness (Fig. 5). The boundary between endotherms and ectotherms approximately follows a diagonal line from the small/Arctic cell to the large/tropical cell. Endothermy increasingly dominates above this line and ectothermy increasingly dominates below it. The increase in endothermy with size can be attributed to the greater ability to retain heat with increasing body mass (Kleiber 1972). We interpret the increase of endothermy with cold as an effect of TPS. In warm water only fast-swimming toothed whales can compete with large fish as pursuit predators. In cold and cool water pursuit-diving birds and pinnipeds are able to capture ectothermic prey whose swimming speeds are slowed by low temperatures (forward TPS). Use of warmer waters by these divers may be blocked by their decreased ability to capture ectothermic prey at higher temperatures (forward TPS), by predation from sharks whose locomotion is enhanced by warm water (reverse TPS) or by both. For poorly insulated partial endotherms cold water increases the cost of maintaining elevated body temperatures. In cold water, endothermic predators are more efficient than ectotherms and partial endotherms in capturing ectothermic prey; hence, in Arctic waters medium and large fish predators are excluded in favour of endotherms.

Low productivity in tropical waters has been widely invoked to explain the dearth of pursuit-diving birds and pinnipeds at low latitudes (Ainley 1977, Heath 2002, Perrin et al. 2002). If tropical productivity levels set the range boundaries of pursuit-diving birds and pinnipeds, we would expect that (1) pursuit-diving birds and pinnipeds will occupy waters up to edge of the tropical zone and (2) those tropical waters that have good productivity will be occupied by pursuitdiving birds and pinnipeds.

Neither expectation is met. There are broad bands of habitat, unoccupied by pursuit-diving birds and pinnipeds, between the tropics and the northern and southern ranges of these animals (Figs. $1 \& 2$ ). The lack of pursuit-diving birds and pinnipeds in these warm temperate bands cannot be explained by lack of food. Given that the sizes of prey taken by fishers and by pursuit-diving birds and pinnipeds broadly overlap (Cairns \& Reddin 2000), mean fisheries landings $\mathrm{km}^{-2}$ of continental shelf/slope in the northeast Pacific and northwest Atlantic serve as an approximate guide to regional productivity of food suitable for these predators. Fisheries landings $\mathrm{km}^{-2}$ of continental shelf/slope show no sharp decrease at the range edge of pursuitdiving birds and pinnipeds (Fig. 4). In the West Atlantic summer populations of pursuit-diving birds and pinnipeds are negligible off the US coast but massive in Canadian waters to the north, although US landings $\mathrm{km}^{-2}$ of shelf/slope equal or exceed those of Canada (Fig. 4).

Contrary to expectation (2), the great majority of tropical waters with good productivity is unoccupied by pursuit-diving birds and pinnipeds. A substantial area (8.3 million $\mathrm{km}^{2}$ ) of the tropical zone has medium or high productivity (>150 $\mathrm{g} \mathrm{C} \mathrm{m}^{-2} \mathrm{yr}^{-1}$ ), but only $5.1 \%$ of this habitat is occupied by pinnipeds and none is occupied by pursuit-diving birds (Figs. 1 \& 2). If tropical productivity controls the distribution of pursuitdiving birds and pinnipeds, these predators should occupy those tropical waters that are productive. We conclude that low tropical productivity cannot explain the worldwide distribution patterns of pursuit-diving birds and pinnipeds.

In deep oceanic waters of the tropical zone, prey is typically concentrated in highly mobile patches, which are exploited by fast-swimming predators (tunas, sharks and dolphins) and by birds with gliding flight (Au 1991, Weimerskirch 2007). Ainley (1977) proposed that pursuit-diving birds cannot occupy such waters because their high cost of locomotion precludes travel between widely spaced and ephemeral food patches. Reijnders et al. (1993) suggested that pinnipeds are largely excluded from the tropics by the high air temperatures they encounter while hauled out. Bathing in the sea dissipates excess heat acquired on land, but this exposes the animal to shark predation (Riedman 1990). These are plausible impediments to the use of tropical waters by pursuit-diving birds and pinnipeds. However, these hypotheses do not explain the absence of pursuit-diving birds and pinnipeds from broad bands of warm temperate water between their northern and southern distributional limits and the tropics (Fig. 1).

Ainley \& Boekelheide (1983) noted that the evolutionary appearance of small toothed whales in the Pliocene roughly coincided with the extinction of a number of flightless diving birds. These authors suggested that the near-absence of pursuit-diving birds in the tropics may stem from competition with toothed whales. However, this hypothesis does not explain the current coexistence of pursuit-diving birds and small toothed whales in cool and cold waters.

The present study shows that the distributions of major vertebrate groups in the world ocean correspond 
to temperature zones and proposes that temperaturedependent predation dynamics is the major structuring force underlying these patterns. This does not preclude influences from other factors. We view temperature as setting overall geographic boundaries for major vertebrate groups, but within these boundaries numerous other biotic and abiotic factors, notably food supply (Cairns 1992, Ferguson \& Higdon 2006), may powerfully affect distribution and abundance.

World mean air temperatures are projected to rise by $1.6^{\circ} \mathrm{C}$ by 2050 and $3^{\circ} \mathrm{C}$ by 2100 (Houghton et al. 2001). Given that long-term ocean temperatures typically rise at the rate of 50 to $90 \%$ that of air temperature (Houghton et al. 1995), expected increases in mean ocean temperatures would be on the order of 0.8 to $1.4^{\circ} \mathrm{C}$ by 2050 and 1.5 to $2.7^{\circ} \mathrm{C}$ by 2100 . Densities of pursuit-diving birds and pinnipeds may vary from high to nil between adjacent areas whose mean summer SSTs differ by only 1 to $2^{\circ} \mathrm{C}$ (Fig. 3), reflecting temperature-sensitive distributional limits. Increasing ocean temperatures are likely to cause range contractions that bring about the disappearance of major populations of pursuit-diving birds and pinnipeds in the present century. A concerted research thrust in marine thermal ecology is needed to clarify the mechanisms by which temperature influences interactions among marine animals and constrains community structure. The key feature of this campaign will be a global, rather than a regional or local, perspective. Tools from the rapidly advancing fields of animal instrumentation (Cooke et al. 2004, Block 2005) and distributional analysis (Elith et al. 2006, Kaschner et al. 2006) will aid this work. As ocean temperatures rise, there is an urgent need for the findings and insights of such an enterprise.

Acknowledgements. We thank S. Cairns for cartographic assistance and L. Ballance, C. Francis, B. Sjare and R. Tallman for valuable comments.

\section{LITERATURE CITED}

Adam PJ, Garcia GG (2003) New information on the natural history, distribution and skull size of the extinct (?) West Indian monk seal, Monachus tropicalis. Mar Mamm Sci 19:297-317

Ainley DG (1977) Feeding methods in seabirds: a comparison of polar and tropical nesting communities in the eastern Pacific Ocean. In: Llano GA (ed) Adaptations within Antarctic ecosystems. Gulf Publishing, Houston, TX, p 669-685

Ainley DG, Boekelheide RJ (1983) An ecological comparison of oceanic seabird communities of the South Pacific Ocean. Stud Avian Biol 8:2-23

Alexander MA, Penland C (1996) Variability in a mixed layer ocean model driven by stochastic atmospheric forcing. J Clim 9:2424-2442

Antas PTZ (1991) Status and conservation of seabirds breeding in Brazilian waters. In: Croxall JP (ed) Seabird status and conservation: a supplement. International Council for Bird Preservation Publication No. 11, Cambridge, p 141-158

Antonelis GA, Baker JD, Johanos TC, Braun RC, Harting AL (2006) Hawaiian monk seal (Monachus schauinslandi): status and conservation issues. Atoll Res Bull 543:75-101

Ashmole NP (1971) Seabird ecology and the marine environment. In: Farne DS, King JR (eds) Avian biology, Vol 1. Academic Press, New York, p 223-286

Au DW (1991) Polyspecific nature of tuna schools: shark, dolphin and seabird associates. Fish Bull (Wash DC) 89: 343-354

Baird RW (2001) Status of harbour seals Phoca vitulina in Canada. Can Field Nat 115:663-675

Baum JK, Myers RA, Kehler DG, Worm B, Harley SJ, Doherty PA (2003) Collapse and conservation of shark populations in the Northwest Atlantic. Science 299:389-392

Behrenfeld MJ, Falkowski PG (1997) Photosynthetic rates derived from satellite-based chlorophyll concentration. Limnol Oceanogr 42:1-20

Bernal D, Dickson KA, Shadwick RE, Graham JB (2001) Review: analysis of the evolutionary convergence for high performance swimming in lamnid sharks and tunas. Comp Biochem Physiol A 129:695-726

Bigg MA, Ellis GM, Cottrell P, Milette L (1990) Predation by harbour seals and sea lions on adult salmon in Comox Harbour and Cowichan Bay, British Columbia. Can Tech Rep Fish Aquat Sci 1769:1-31

Bingham M (1998) Penguins of South America and the Falkland Islands. Penguin Conserv 11:8-15

Block BA (2005) Physiological ecology in the 21st century: advancements in biologging science. Integr Comp Biol 45:305-320

Boersma PD (1978) Breeding patterns of Galapagos penguins as an indicator of oceanographic conditions. Science 200: 1481-1483

Bowen WD, Tully D, Boness DJ, Bulheier BM, Marshall GJ (2002) Prey-dependent foraging tactics and prey profitability in a marine mammal. Mar Ecol Prog Ser 244:235-245

Bowen WD, Ellis SL, Iverson SJ, Boness DJ (2003) Maternal and newborn life-history traits during periods of contrasting population trends: implications for explaining the decline of harbour seals (Phoca vitulina), on Sable Island. J Zool 261:155-163

Brooke M de L (2004) The food consumption of the world's seabirds. Proc Biol Sci 271:S246-S248

Buckley PA, Buckley FG (1984) Seabirds of the north and middle Atlantic coast of the United States: their status and conservation. In: Croxall JP, Evans PGH, Schreiber RW (eds) Status and conservation of the world's seabirds. International Council for Bird Preservation Technical Publication No. 2, Cambridge, p 101-133

Bundy A, Lilly GR, Shelton PA (2000) A mass balance model of the Newfoundland-Labrador Shelf. Can Tech Rep Fish Aquat Sci: 2310

Cairns DK (1986) Plumage colour in pursuit-diving seabirds: Why do penguins wear tuxedos? Bird Behav 6:58-65

Cairns DK (1992) Population regulation of seabird colonies. Current Ornithol 9:37-61

Cairns DK, Reddin DG (2000) The potential impact of seal and seabird predation on North American Atlantic salmon. Canadian Stock Assessment Secretariat Res Doc: 2000/12. Department of Fisheries and Oceans, Ottawa

Cairns DK, Chapdelaine G, Montevecchi WA (1991) Prey exploitation by seabirds in the Gulf of St. Lawrence. In: Therriault JC (ed) The Gulf of St. Lawrence: small ocean or big estuary? Can Spec Publ Fish Aquat Sci 113:277-291 
Carter HR, Gilmer DS, Takekawa JE, Lowe RW, Wilson UW (1995) Breeding seabirds in California, Oregon and Washington. In: LaRoe ET, Farris GS, Puckett CE, Doran PD, Mac MJ (eds) Our living resources: a report to the nation on the distribution, abundance and health of US plants, animals and ecosystems. US Department of the Interior, National Biological Service, Washington, DC, p 43-49

Christian KA, Tracy CR (1981) The effect of the thermal environment on the ability of hatchling Galapagos land iguanas to avoid predation during dispersal. Oecologia 49: 218-223

Cooke SJ, Hinch SG, Wikelski M, Andersen DC, Kuchel LJ, Wolcott TG (2004) Biotelemetry: a mechanistic approach to ecology. Trends Ecol Evol 19:334-343

Cooper J, Williams AJ, Britton PL (1984) Distribution, population sizes and conservation of breeding seabirds in the Afrotropical region. In: Croxall JP, Evans PGH, Schreiber RW (eds) Status and conservation of the world's seabirds. International Council for Bird Preservation Technical Publication No. 2, Cambridge, p 403-419

- Corkeron PJ, Connor RC (1999) Why do baleen whales migrate? Mar Mamm Sci 15:1228-1245

> Cortés E (1999) Standardized diet compositions and trophic levels of sharks. ICES J Mar Sci 56:707-717

Croxall JP, Lishman GS (1987) The food and feeding ecology of penguins. In: Croxall JP (ed) Seabirds feeding ecology and role in marine ecosystems. Cambridge University Press, Cambridge, p 101-133

Croxall JP, McInnes SJ, Prince PA (1984) The status and conservation of seabirds at the Falkland Islands. In: Croxall JP, Evans PGH, Schreiber RW (eds) Status and conservation of the world's seabirds. International Council for Bird Preservation Technical Publication No. 2, Cambridge, p 271-291

del Hoyo J, Elliott A, Sargatal J (eds) (1992) Handbook of the birds of the world, Vol 1. Lynx Edicions, Barcelona

> Dellinger T, Trillmich F (1999) Fish prey of the sympatric Galapagos fur seals and sea lions: seasonal variation and niche separation. Can J Zool 77:1204-1216

DFO (Department of Fisheries and Oceans) (1987) Canadian fisheries annual statistical review, Vol 20. DFO, Ottawa

DFO (Department of Fisheries and Oceans) (1990) Canadian fishery landings, Vol 11, No. 12. DFO, Ottawa

$>$ Domenici P (2001) The scaling of locomotor performance in predator-prey encounters: from fish to killer whales. Comp Biochem Physiol A 131:169-182

Domenici P, Blake RW (1997) The kinematics and performance of fast-start fish swimming. J Exp Biol 200: 1165-1178

Donoghue M (1997) Seal/fisheries interactions in New Zealand. In: Stone G, Goebel J, Webster S (eds) Pinniped populations, eastern Pacific: status, trends and issues. Monterey Bay Aquarium, Monterey, CA, p 56-62

Drost CA, Lewis DB (1995) Xantus' murrelet (Synthliboramphus hypoleucus). In: Poole A, Gill F (eds) The birds of North America, No. 164. The Academy of Natural Sciences, Philadelphia, PA, and the American Ornithologists' Union, Washington, DC, p 1-23

Duffy DC, Hays C, Plenge MA (1984) The conservation status of Peruvian seabirds. In: Croxall JP, Evans PGH, Schreiber RW (eds) Status and conservation of the world's seabirds. International Council for Bird Preservation Technical Publication No. 2, Cambridge, p 245-259

Elith J, Graham CH, Anderson RP, Dudik M and others (2006) Novel methods improve prediction of species' distributions from occurrence data. Ecography 29:1-23

Escalante R (1991) Status and conservation of seabirds breeding in Uruguay. In: Croxall JP (ed) Seabird status and conservation: a supplement. International Council for Bird Preservation Publication No. 11, Cambridge, p 159-164

Evans PGH (1984a) The seabirds of Greenland: their status and conservation. In: Croxall JP, Evans PGH, Schreiber RW (eds) Status and conservation of the world's seabirds. International Council for Bird Preservation Technical Publication No. 2, Cambridge, p 49-84

Evans PGH (1984b) Status and conservation of seabirds in northwest Europe (excluding Norway and the USSR). In: Croxall JP, Evans PGH, Schreiber RW (eds) Status and conservation of the world's seabirds. International Council for Bird Preservation Technical Publication No. 2, Cambridge, p 293-321

Everett WT, Anderson DW (1991) Status and conservation of the breeding seabirds on offshore Pacific islands of Baja California and the Gulf of California. In: Croxall JP (ed) Seabird status and conservation: a supplement. International Council for Bird Preservation Publication No. 11, Cambridge, p 115-139

Ferguson SH, Higdon JW (2006) How pinnipeds divide up the world: environment, life history and conservation. Oecologia 150:318-329

Ferguson SH, Stirling I, Mcloughlin P (2005) Climate change and ringed seal (Phoca hispida) recruitment in western Hudson Bay. Mar Mamm Sci 21:121-135

Ferrero RC, DeMaster DP, Hill PS, Muto MM, Lopez AL (2000) Alaska marine mammal stock assessments, 2000. NOAA Tech Mem NMFS-AFSC-119

Finley KJ (2001) Natural history and conservation of the Greenland whale, or bowhead, in the Northwest Atlantic. Arctic 54:55-76

Fish FE (2002) Speed. In: Perrin WF, Wursig B, Thewissen JGM (eds) Encyclopedia of marine mammals. Academic Press, San Diego, CA, p 1161-1163

Fonteneau A (2004) Biological overview of tunas stocks and overfishing. FAO Fish Rep No. 700:117-132

FAO (Food and Agricultural Organization) (1994) World review of highly migratory species and straddling stocks. FAO Fish Tech Pap 337:1-70

FAO (Food and Agricultural Organization) (2003) FishStat. FAO, Rome. Available at: www.fao.org/fi/statist/statist.asp

FAO (Food and Agricultural Organization) (2006) Atlas of tuna and billfish catches. Available at: www.fao.org/fi/ atlas/tunabill/english/index.htm.

Forney KA, Barlow J, Muto MM, Lowry M and others (2000) US Pacific marine mammal stock assessments: 2000. NOAA Tech Mem NMFS-SWFSC-300

Fritsches KA, Brill RW, Warrant EJ (2005) Warm eyes provide superior vision in swordfishes. Curr Biol 15:55-58

Gallo-Reynoso JP, Figueroa-Carranza AL (1992) A cookiecutter shark wound on a Guadalupe fur seal male. Mar Mamm Sci 8:428-430

Gandini P, Frere E, Boersma PD (1996) Status and conservation of Magellanic penguins Spheniscus magellanicus in Patagonia, Argentina. Bird Conserv Int 6:307-316

Garrison T (1993) Oceanography. Wadsworth, Belmont, CA

Gaston AJ, Jones IL (1998) The auks alcidae. Oxford University Press, Oxford

Greenwald OE (1974) Thermal dependence of striking and prey capture by gopher snakes. Copeia 1:141-148

Guénette S, Christensen V, Pauly D (eds) (2001) Fisheries impacts on North Atlantic ecosystems: models and analyses. Fisheries Centre Research Reports, Vol 9, No. 4. University of British Columbia, Vancouver

Hammill MO, Stenson GB (1997) Estimated prey consumption by harp seals (Phoca groenlandica), grey seals (Halicho- 
erus grypus), harbour seals (Phoca vitulina) and hooded seals (Cystophora cristata) in the northwest Atlantic. NAFO SCR Doc 97/40, Dartmouth

Hammill MO, Stenson GB (2000) Estimated prey consumption by harp seals (Phoca groenlandica), hooded seals (Cystophora cristata), grey seals (Halichoerus grypus) and harbour seals (Phoca vitulina) in Atlantic Canada. J Northwest Atl Fish Sci 26:1-23

Harris S, Morris P, Wray S, Yalden D (1995) A review of British mammals: population estimates and conservation status of British mammals other than cetaceans. Joint Nature Conservation Committee, Peterborough, England. Available at: www.jncc.gov.uk/publications/review_britishmammals/ default.htm

Hasegawa H (1984) Status and conservation of seabirds in Japan with special attention to the short-tailed albatross. In: Croxall JP, Evans PGH, Schreiber RW (eds) Status and conservation of the world's seabirds. International Council for Bird Preservation Technical Publication No. 2, Cambridge, p 487-500

Heath CB (2002) California, Galapagos and Japanese sea lions. In: Perrin WF, Wursig B, Thewissen JGM (eds) Encyclopedia of marine mammals. Academic Press, San Diego, CA, p 180-186

Heithaus MR, Dill LM (2002) Feeding strategies and tactics. In: Perrin WF, Wursig B, Thewissen JGM (eds) Encyclopedia of marine mammals. Academic Press, San Diego, CA, p 412-422

Hiruki LM, Gilmartin WG, Becker BL, Stirling I (1993) Wounding in Hawaiian monk seals (Monachus schauinslandi). Can J Zool 71:458-468

Houghton JT, Meira Filho LG, Callander BA, Harris N, Kattenberg A, Maskell K (eds) (1995) The science of climate change. Intergovernmental Panel on Climate Change, Cambridge University Press, Cambridge

Houghton JT, Ding Y, Griggs DJ, Noguer M and others (eds) (2001) Climate change 2001: the scientific basis. Intergovernmental Panel on Climate Change, Cambridge University Press, Cambridge

Howland HC (1974) Optimal strategies for predator avoidance: the relative importance of speed and manoeuvrability. J Theor Biol 47:333-350

Johnsgard PA (1987) Diving birds of North America. University of Nebraska Press, Lincoln, NE

Johnsgard PF (1993) Cormorants, darters and pelicans of the world. Smithsonian Institution Press, Washington, DC

Karpouzi VS (2005) Modelling and mapping trophic overlap between fisheries and the world's seabirds. MSc thesis, University of British Columbia, Vancouver

Kaschner K, Watson R, Trites AW, Pauly D (2006) Mapping worldwide distributions of marine mammal species using a relative environmental suitability (RES) model. Mar Ecol Prog Ser 316:285-310

Kingsley MCS (1998) The numbers of ringed seals (Phoca hispida) in Baffin Bay and associated waters. In: HeideJorgensen MP, Lydersen C (eds) Ringed seals in the North Atlantic. North Atlantic Marine Mammal Commission, Tromsø, p 181-196

Kitaysky AS, Golubova EG (2000) Climate change causes contrasting trends in reproductive performance of planktivorous and piscivorous alcids. J Anim Ecol 69:248-262

Kleiber M (1972) Body size, conductance for animal heat flow and Newton's law of cooling. J Theor Biol 37:139-150

Klimley AP, Beavers SC, Curtis TH, Jorgensen SJ (2002) Movements and swimming behavior of three species of sharks in La Jolla Canyon, California. Environ Biol Fishes 63:117-135
Lavigne DM, Brooks RJ, Rosen DA, Galbraith DA (1989) Cold, energetics and populations. In: Wang LCH (ed) Advances in comparative and environmental physiology, Vol 4. Springer-Verlag, Berlin, p 403-432

Le Boeuf BJ, Crocker DE, Costa DP, Blackwell SB, Webb PM, Houser DS (2000) Foraging ecology of northern elephant seals. Ecol Monogr 70:353-382

Lehodey P, Chai F, Hampton J (2003) Modelling climaterelated variability of tuna populations from a coupled ocean-biogeochemical-populations dynamics model. Fish Oceanogr 12:483-494

Lensink CJ (1984) The status and conservation of seabirds in Alaska. In: Croxall JP, Evans PGH, Schreiber RW (eds) Status and conservation of the world's seabirds. International Council for Bird Preservation Technical Publication No. 2, Cambridge, p 13-27

Lock AR, Brown RGB, Gerriets SH (1994) Gazetteer of marine birds in Atlantic Canada. Canadian Wildlife Service, Dartmouth

Lucas Z, Stobo WT (2000) Shark-inflicted mortality on a population of harbour seals (Phoca vitulina) at Sable Island, Nova Scotia. J Zool 252:405-414

Manuwal DA, Thoresen AC (1993) Cassin's auklet Ptychoramphus aleuticus In: Poole A, Gill F (eds) The birds of North America, No. 50. The Academy of Natural Sciences, Philadelphia, PA, and the American Ornithologists' Union, Washington, DC, p 1-18

Martin RA, Hammerschlag N, Collier RS, Fallows C (2005) Predatory behaviour of white sharks Carcharodon carcharias at Seal Island, South Africa. J Mar Biol Assoc UK 85:1121-1135

McCarthy JJ, Canziani OF, Leary NA, Dokken DJ, White KS (eds) (2001) Climate change 2001: impacts, adaptation and vulnerability. Intergovernmental Panel on Climate Change, Cambridge University Press, Cambridge

McMahon CR, Hays GC (2006) Thermal niche, large-scale movements and implications of climate change for a critically endangered marine vertebrate. Glob Change Biol 12: 1330-1338

NOAA (National Oceanic and Atmospheric Administration) (1990) Fisheries of the United States, No. 8900. NOAA, Washington, DC

NAFO (Northwest Atlantic Fisheries Organization) (1993) Northwest Atlantic Fisheries Organization Statistical Bulletin, Vol 39. NAFO, Dartmouth

Perrin WF, Wursig B, Thewissen JGM (2002) Encyclopedia of marine mammals. Academic Press, San Diego, CA

Randall BM, Randall RM, Compagno LJV (1988) Injuries to jackass penguins (Spheniscus demersus): evidence for shark involvement. J Zool 214:589-599

Reijnders P, Brasseur S, van der Toorn J, van der Wolf P and others (1993) Seals, fur seals, sea lions, and walrus. International Union for the Conservation of Nature and Natural Resources, Gland

Riedman M (1990) The pinnipeds: seals, sea lions, and walruses. University of California Press, Berkeley, CA

Robertson CJR, Bell BD (1984) Seabird status and conservation in the New Zealand region. In: Croxall JP, Evans PGH, Schreiber RW (eds) Status and conservation of the world's seabirds. International Council for Bird Preservation Technical Publication No. 2, Cambridge, p 573-586

Rodway MS (1991) Status and conservation of breeding seabirds in British Columbia. In: Croxall JP (ed) Seabird status and conservation: a supplement. International Council for Bird Preservation Publication No. 11, Cambridge, p 43-102 
Schreer JF, Kovacs KM, Hines RJO (2001) Comparative diving patterns of pinnipeds and seabirds. Ecol Monogr 71:137-162

Shaughnessy PD (1985) Interactions between fisheries and Cape fur seals in southern Africa. In: Beddington JR, Beverton RJH, Lavigne DM (eds) Marine mammals and fisheries. Allen and Unwin, London, p 119-134

Solomon S, Qin D, Manning M, Chen Z and others (eds) (2007) Climate change 2007: the physical science basis. Fourth Assessment Report of the Intergovernmental Panel on Climate Change. Cambridge University Press, Cambridge

Stewart BS (1997) California pinnipeds: population trends, trans-jurisdictional migrations and ecological function in large marine ecosystems of the eastern North Pacific Ocean. In: Stone G, Goebel J, Webster S (eds) Pinniped populations, eastern Pacific: status, trends and issues. Monterey Bay Aquarium, Monterey, CA, p 13-21

Taylor EW, Egginton S, Taylor SE, Butler PJ (1996) Factors which may limit swimming performance at different temperatures. In: Wood CM, MacDonald DG (eds) Global warming: implications for freshwater and marine fish. Society for Experimental Biology Seminar Series 61. Cambridge University Press, Cambridge, p 105-133

US Navy (1981) US Navy marine climatic atlas of the world, Vol 9. US Navy, Washington, DC

Valdimarsson SK, Metcalfe NB (1998) Shelter selection in juvenile Atlantic salmon, or why do salmon seek shelter in winter? J Fish Biol 52:42-49

Wallace EAH, Wallace GE (1998) Brandt's cormorant (Phalacrocorax penicillatus). In: Poole A, Gill F (eds) The birds of North America, No. 362. The Academy of Natural Sciences, Philadelphia, PA, and the American Ornithologists' Union, Washington, DC, p 1-27

Wardle CS (1980) Effects of temperature on the maximum swimming speed of fishes. In: Ali MA (ed) Environmental

Editorial responsibility: Rory Wilson,

Swansea, UK physiology of fishes. Plenum, New York, p 519-531

Waring GT, Quintal JM, Swartz SL (eds) (2000) US Atlantic and Gulf of Mexico marine mammal stock assessments2000. NOAA Tech Mem NMFS-NE-162

Webb PW (1978) Temperature effects on acceleration of rainbow trout, Salmo gairdneri. J Fish Res Board Can 35: 1417-1422

Weimerskirch H (2007) Are seabirds foraging for unpredictable resources? Deep-Sea Res II 54:211-223

Welch HE, Bergmann MA, Siferd TD, Martin KA and others (1992) Energy flow through the marine ecosystem of the Lancaster Sound Region, Arctic Canada. Arctic 45: 343-357

Weller DW (2002) Predation on marine mammals. In: Perrin WF, Wursig B, Thewissen JGM (eds) Encyclopedia of marine mammals. Academic Press, San Diego, CA, p 985-994

Westlake RL, Gilmartin WG (1990) Hawaiian monk seal pupping locations in the northwestern Hawaiian Islands. Pac Sci 44:366-383

Williams TD (1995) The penguins Spheniscidae. Oxford University Press, Oxford

Williams TM (2002) Swimming. In: Perrin WF, Wursig B, Thewissen JGM (eds) Encyclopedia of marine mammals. Academic Press, San Diego, CA, p 1213-1222

Wilson RS, Franklin CE, Davison W, Kraft P (2001) Stenotherms at subzero temperatures: thermal dependence of swimming performance in Antarctic fish. J Comp Physiol B 171:263-269

Yorio P, Frere E, Gandini P, Conway W (1999) Status and conservation of seabirds breeding in Argentina. Bird Conserv Int 9:299-314

Zhang YP, Ji X (2004) The thermal dependence of food assimilation and locomotor performance in southern grass lizards, Takydromus sexlineatus (Lacertidae). J Therm Biol 29:45-53

Submitted: January 7, 2007; Accepted: October 18, 2007 Proofs received from author(s): March 6, 2008 